\title{
Water relations in parsley plants cultivated in brackish nutrient solutions of different cationic natures
}

\author{
Juliana B. Martins ${ }^{1}$, José A. Santos Júnior ${ }^{1}$, Victor P. Bartusch ${ }^{1}$, Hans R. Gheyi², \\ Egídio Bezerra Neto ${ }^{1} \&$ Manassés M. da Silva ${ }^{1}$
}

\begin{abstract}
${ }^{1}$ Universidade Federal Rural de Pernambuco/Programa de Pós-Graduação em Engenharia Agrícola. Recife, PE, Brasil. E-mail: julianaabmartins@gmail.com (Corresponding author) - ORCID: 0000-0002-9433-3230; joseamilton@ufrpe.br - ORCID: 0000-0002-1656-7103; victorbartusch@outlook.com - ORCID: 0000-0002-3652-2180; egidiobezerra.neto@gmail.com - ORCID: 0000-0002-6204-8291; manasses.mesquita@ufrpe.br - ORCID: 0000-0002-3316-8024 ${ }^{2}$ Universidade Federal do Recôncavo da Bahia/Núcleo de Engenharia de Água e Solo. Cruz das Almas, BA, Brasil. E-mail: hans@pq.cnpq.br - ORCID: 0000- 0002-1066-0315
\end{abstract}

\begin{abstract}
The analysis of plant response to the cationic variability of the waters, in addition to the osmotic component, is indispensable in the context of salt stress. Thus, between October 2017 and February 2018, in Recife, PE, Brazil ( $8^{\circ} 1^{\prime} 7^{\prime \prime} \mathrm{S}$ and $34^{\circ} 56^{\prime} 53^{\prime \prime} \mathrm{W}$, and altitude of $6.5 \mathrm{~m}$ ), the present study was carried out to evaluate the water relations of parsley plants (Petroselinum crispum), cv. Graúda Portuguesa, cultivated in brackish nutrient solutions (electrical conductivities of 1.7, 2.7, 3.7, 4.7, 5.7 and $6.7 \mathrm{dS} \mathrm{m}^{-1}$ ) prepared in waters with different cationic natures $\left(\mathrm{NaCl}, \mathrm{CaCl}_{2}, \mathrm{KCl}\right.$ and $\mathrm{MgCl}_{2}$ ). The experimental design was completely randomized, in a $6 \times 4$ factorial scheme, with five repetitions, and five plants per plot. Two experiments were conducted sequentially under this statistical design; in the first, the evapotranspired depth was replaced with supply water $\left(0.12 \mathrm{dS} \mathrm{m}^{-1}\right)$ and in the second, with the respective brackish water. The increment in nutrient solution salinity influences the fresh and dry biomass and the percentages of total, shoot and root dry masses, and this increment led to different behavior in parsley physiology under the different cationic natures of the water, being less harmful with the use of supply water to replace the evapotranspired depth and with $\mathrm{CaCl}_{2}$ water with electrical conductivity above $5.7 \mathrm{dS} \mathrm{m}^{-1}$, in the replacement with brackish water.
\end{abstract}

Key words: Petroselinum crispum, soilless cultivation, water content

\section{Relações hídricas em plantas de salsa cultivada em soluções nutritivas salobras de naturezas catiônicas distintas}

RESUMO: A análise da resposta das plantas à variabilidade catiônica das águas, somado ao componente osmótico, é imprescindível no contexto do estresse salino. Neste sentido, entre outubro de 2017 e fevereiro de 2018, em Recife, PE ( $8^{\circ} 1^{\prime} 7^{\prime \prime}$ S e $34^{\circ} 56^{\prime \prime} 53^{\prime \prime}$ O, e altitude de 6,5 m), o presente trabalho foi desenvolvido com o objetivo de avaliar as relações hídricas em plantas de salsa (Petrocelinum crispum), cv. Graúda Portuguesa, cultivadas em soluções nutritivas salobras (condutividades elétricas de 1,$7 ; 2,7 ; 3,7 ; 4,7 ; 5,7 ; 6,7 \mathrm{dS} \mathrm{m}^{-1}$ ) preparadas em águas com naturezas catiônicas diferentes $\left(\mathrm{NaCl}, \mathrm{CaCl}_{2}, \mathrm{KCl}\right.$ e $\left.\mathrm{MgCl}_{2}\right) . \mathrm{O}$ delineamento experimental adotado foi o inteiramente casualizado, em esquema fatorial 6 x 4, com cinco repetições, cada uma consistindo de cinco plantas. Dois experimentos foram realizados sequencialmente sob esta configuração estatística; no primeiro, a reposição da lâmina evapotranspirada foi efetuada com água de abastecimento $\left(0,12 \mathrm{dS} \mathrm{m}^{-1}\right)$ e no segundo, com a respectiva água salobra. O incremento da salinidade da solução nutritiva influencia as fitomassas frescas e secas e os percentuais de massa seca totais, da parte aérea e da raiz e, esse incremento proporcionou comportamento divergente na fisiologia da salsa frente às distintas naturezas catiônicas da água, sendo menos prejudicial com uso de água de abastecimento na reposição da lâmina e com água $\mathrm{CaCl}_{2}$ com condutividade elétrica acima de $5,7 \mathrm{dS} \mathrm{m}^{-1}$, na reposição com água salobra.

Palavras-chave: Petroselinum crispum, cultivo sem solo, teor de água

Ref. 202587 - Received 07 Jun, 2018 • Accepted 16 Jul, 2019 • Published 31 Jul, 2019 


\section{INTRODUCTION}

Studies on salt stress in plants, especially in the context of the osmotic component (Nobre et al., 2014; Santos Júnior et al., 2016), have been addressed by different authors in the production of leafy vegetables (Silva et al., 2013b; Borges et al., 2014; Bernardes et al., 2015; Santos Júnior et al., 2015).

However, brackish waters are composed of cations $\left(\mathrm{Ca}^{2+}, \mathrm{K}^{+}, \mathrm{Mg}^{2+}\right.$ and $\left.\mathrm{Na}^{+}\right)$and anions $\left(\mathrm{HCO}_{3}^{-}, \mathrm{CO}_{3}{ }^{2-}, \mathrm{Cl}^{-}\right.$and $\mathrm{SO}_{4}^{2-}$ ) (Holanda et al., 2016), in different proportions and combinations, which also cause other impacts on plants (Lima et al., 2018) and on the nutrient solution (Terraza et al., 2016).

In soilless cultivation, the osmotic and ionic effects cited have been addressed with the use of salt stress mitigation strategies, such as the replacement of the evapotranspired depth, as verified in studies with arugula (Eruca sativa) and other vegetables under salt stress (Silva et al., 2012, 2015; Soares et al., 2016; Campos Júnior et al., 2018).

In fact, studies on the response of the water relations of vegetables to the different cationic natures of brackish nutrient solutions are still incipient, although it is already known that water consumption, water content in the plant as well as the water use efficiency of leafy vegetables are negatively influenced by the osmotic component of salt stress (Paulus et al., 2012; Silva et al., 2013a; Bione et al., 2014).

Therefore, the present study was conducted to evaluate the water relations in parsley plants exposed to brackish nutrient solutions of different cationic natures.

\section{Material ANd Methods}

The experiments were carried out between October 2017 and February 2018 in an arched greenhouse with skylight, belonging to the Departamento de Engenharia Agrícola of UFRPE, Recife, PE, Brazil ( $8^{\circ} 1^{\prime} 7^{\prime \prime} \mathrm{S}$ and $34^{\circ} 56^{\prime} 53^{\prime \prime} \mathrm{W}$, and altitude of $6.5 \mathrm{~m}$ ).

The city of Recife is characterized by an Am climate according to the Köppen-Geiger classification (Alvares et al., 2013), with average values of temperature, relative humidity and rainfall of $25.9{ }^{\circ} \mathrm{C}, 78.3 \%$ and $1,757 \mathrm{~mm}$, respectively. The hydroponic system consisted of cultivation channels made of PVC pipe with length of $6 \mathrm{~m}$ and nominal diameter of $100 \mathrm{~mm}$, with $60-\mathrm{mm}$-diameter holes every $0.14 \mathrm{~m}$. Both ends were connected to elbows with outlets that maintained a 0.04 -m-deep film of nutrient solution in the pipe (Santos Júnior et al., 2016).

The experimental design was completely randomized in a $6 \times 4$ factorial scheme, with five repetitions containing five plants per plot. Six levels of nutrient solution electrical conductivity were tested $\left(\mathrm{EC}_{\mathrm{ns}}=1.7 ; 2.7 ; 3.7 ; 4.7 ; 5.7 ; 6.7 \mathrm{dS} \mathrm{m}^{-1}\right)$ prepared in brackish water, salinized with $\mathrm{NaCl}, \mathrm{CaCl}_{2}, \mathrm{KCl}$ and $\mathrm{MgCl}_{2}$. Two successive experiments were carried out: in the first, the evapotranspired depth was replaced with supply water from the municipal network (SW), beginning on October 13,2017 ; in the second, with the respective brackish waters (BW), beginning on December 21, 2017.

The waters were prepared by dissolving $\mathrm{NaCl}, \mathrm{CaCl}_{2} \cdot 2 \mathrm{H}_{2} \mathrm{O}$, $\mathrm{KCl}$ and $\mathrm{MgCl}_{2} \cdot 6 \mathrm{H}_{2} \mathrm{O}$ in supply water $\left(\mathrm{ECw}=0.12 \mathrm{dS} \mathrm{m}{ }^{-1}\right)$, establishing the following levels of water electrical conductivity (ECw): 0.12 (control); 1.12; 2.12; 3.12; 4.12 and $5.12 \mathrm{dS} \mathrm{m}^{-1}$. These waters were stored in $90-\mathrm{L}$ reservoirs and then, to obtain the nutrient solution, adequate quantity of fertilizers proposed by Furlani et al. (1999) was solubilized. Nutrient solution management was carried out individually in each pipe, according to treatments, and consisted of continuous reuse of each level of $\mathrm{EC}_{\mathrm{ns}}$. The evapotranspired depth was replaced every seven days and the nutrient solution was manually recirculated, twice a day, reapplying/circulating a volume of solution equivalent to twice the capacity of the pipe up to the established depth of $0.04 \mathrm{~m}$.

Electrical conductivity $\left(\mathrm{EC}_{\mathrm{ns}}\right)$ and $\mathrm{pH}_{\mathrm{ns}}$ was monitored every two days. In the phytosanitary aspect, no incidences of pests and diseases were recorded. During the experiments, inside the greenhouse, for the first and second experiment, there was a maximum average temperatures of 39 and $36^{\circ} \mathrm{C}$ and minimum average temperatures of 33.5 and $31.5^{\circ} \mathrm{C}$, as well as average relative humidity of 60.9 and $61.5 \%$ and minimum relative humidity of 43.8 and $44.6 \%$, respectively.

The studied crop was parsley (Petroselinum crispum), cv. Graúda Portuguesa. Its sowing was performed with 45 seeds in 180-mL plastic cups drilled at the bottom and on the sides, filled with coconut fiber as substrate. Initially, moisture was maintained by spraying supply water on the seedlings, until the transfer to the hydroponic module, which occurred ten days after sowing (DAS), period required for parsley emergence.

At the end of each test (50 DAS), the following variables were evaluated: water consumption (WC), by the relationship between the volume consumed and the number of cups containing bunches in the hydroponic cultivation channel; water use efficiency in the production of fresh and dry biomass (WUE-SFB and WUE-SDB), through the relationship between the production and the water volume consumed; water contents in the plant (WCP), in the shoots (WCS) and in the roots (WCR), according to Benincasa (2003), by dividing the fresh mass by the respective dry mass; shoot biomass production index (SBPI), according to Benincasa (2003), by dividing shoot dry mass by the total dry mass; and the ratio between root and shoot biomass, which was calculated by dividing the total dry mass of the root system by the total dry mass of the shoots of the plants.

The results were subjected to analysis of variance by $\mathrm{F}$ test for each experiment individually. Means relative to the cationic nature of the water were compared by Tukey test and those referring to the electrical conductivity of the nutrient solutions by regression, both at $\mathrm{p} \leq 0.05$ by $\mathrm{F}$ test, using the program SISVAR for data processing (Ferreira, 2011).

\section{Results AND Discussion}

The electrical conductivity of the nutrient solution $\left(\mathrm{EC}_{\mathrm{ns}}\right)$ decreased at all levels and cationic natures studied, when the evapotranspired depth was replaced with supply water with decrease reaching up to $15 \%$ of the initial $\mathrm{EC}_{\mathrm{ns}}$ adopted. In the replacement with brackish water, there was an increase in comparison to the initial $\mathrm{EC}_{\mathrm{ns}}$, which was also observed by Silva et al. (2015), who replaced the evapotranspired depth with 
brackish water based on $\mathrm{KCl}$ and $\mathrm{MgCl}_{2}$ and found increments of 25.7 and $38.47 \%$, respectively, from 35 DAS. This variation exceeded the tolerance limit of $25 \%$ suggested by Melo et al. (1999). However, in the solutions based on $\mathrm{NaCl}$ and $\mathrm{CaCl}_{2}$, the increment was smaller and basically the same, 21.01 and $21.28 \%$, respectively, at 44 DAS.

Replacement with supply water caused a reduction in $\mathrm{pH}_{\mathrm{ns}}$ of up to $15 \%$, from 35 DAS in the solutions based on $\mathrm{KCl}$, reaching 5.5 at the end of the cycle. A higher negative amplitude (11.47\%) was observed for the $3.7 \mathrm{dS} \mathrm{m}^{-1}$ in the nutrient solution based on $\mathrm{KCl}$ from $35 \mathrm{DAS}$. When $\mathrm{NaCl}, \mathrm{CaCl}_{2}$ and $\mathrm{MgCl}_{2}$ were used, the reductions in the $\mathrm{pH}_{\mathrm{ns}}$ at $50 \mathrm{DAS}$ were equal to $4.54,7.93$ and $9.67 \%$, respectively. In general, the $\mathrm{pH}_{\mathrm{ns}}$ variations in this study did not exceed the range from 5.5 to 6.5 suggested by Silva et al. (2018), which would cause problems in the absorption of nutrients.

The values of water consumption per bunch with the replacement using supply water (Figure 1A), in treatments with solutions based on $\mathrm{CaCl}_{2}$ and $\mathrm{MgCl}_{2}$, were on average 45.95 and $20.05 \%$ lower than the average consumption of the

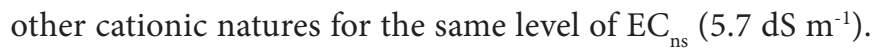
This probably occurred because monovalent cations can be absorbed more rapidly than bivalent cations (Abrahão et al., 2014), corroborating the fact that a similar water consumption was observed in plants under solutions based on $\mathrm{NaCl}$ and $\mathrm{KCl}$ for most $\mathrm{EC}_{\mathrm{ns}}$ levels, except 3.7 and $4.7 \mathrm{dS} \mathrm{m} \mathrm{m}^{-1}$.

Indeed, under these conditions of replacement of the solution, in the treatment of $1.7 \mathrm{dS} \mathrm{m}^{-1}$, plants consumed per week, on average, $0.998,0.909,0.958$ and $0.971 \mathrm{~L} \mathrm{bunch}^{-1}$ when
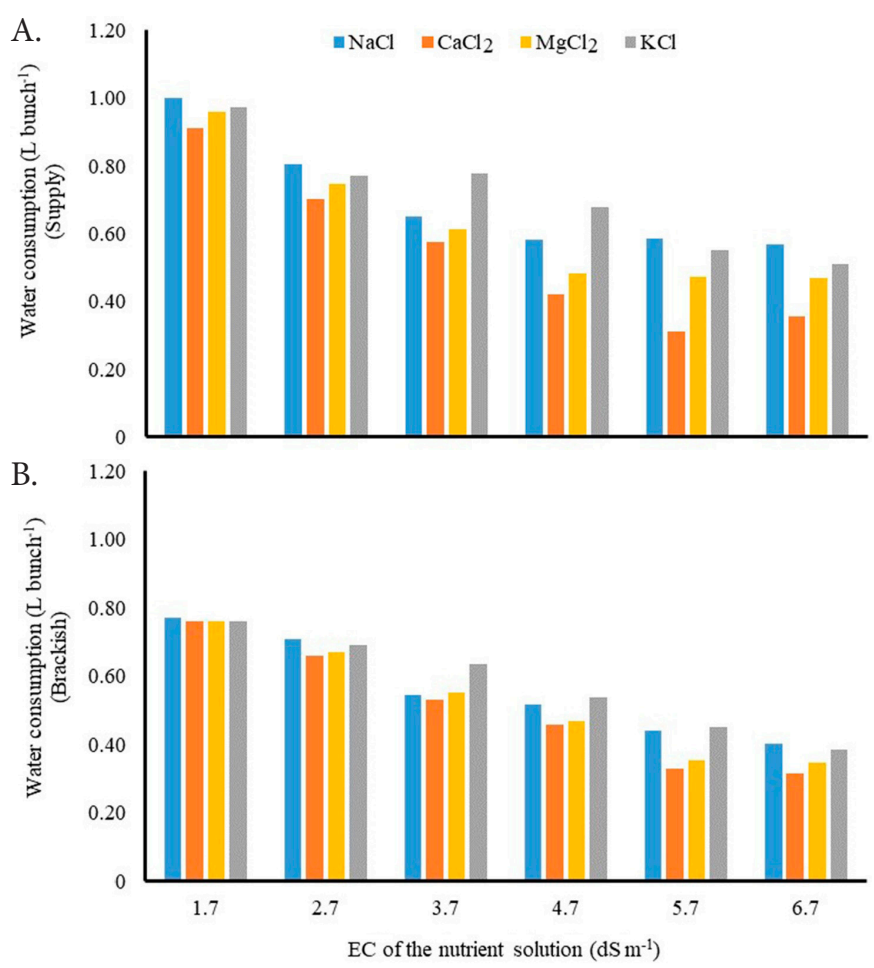

Figure 1. Water consumption of parsley plants, cv. Graúda Portuguesa in a cycle of 50 days, cultivated in brackish nutrient solutions of different cationic natures at each electrical conductivity (EC) of the nutrient solution, with replacement of evapotranspiration with supply water (A) and with the respective brackish water $(\mathrm{B})$
$\mathrm{NaCl}, \mathrm{CaCl}_{2}, \mathrm{MgCl}_{2}$ and $\mathrm{KCl}$ were used, respectively, whereas in the treatment of $6.7 \mathrm{dS} \mathrm{m}^{-1}$, the average weekly consumption was $0.568,0.355,0.468$ and $0.510 \mathrm{~L} \mathrm{bunch}^{-1}$ (Figure 1A), i.e., on an average water consumption lower than $5 \mathrm{~L}$ during the crop cycle.

With the use of brackish water in the replacement (Figure $1 \mathrm{~B})$, water consumption decreased as $\mathrm{EC}_{\mathrm{ns}}$ increased in all treatments, regardless of the cationic nature tested, as already verified for lettuce and beet (Paulus et al., 2012; Silva et al., 2013a). It is worth pointing out, however, the decrease in water consumption of plants grown in a solution based on $\mathrm{CaCl}_{2}$, mainly for the concentrations of 5.7 and $6.7 \mathrm{dS} \mathrm{m}^{-1}$.

This fact can be attributed to the precipitation observed in the reservoirs of the solutions based on $\mathrm{CaCl}_{2}$, from the concentration of $5.7 \mathrm{dS} \mathrm{m}^{-1}$, due to the presence of phosphate in the nutrient solution, which contributes to the formation of calcium phosphate, which in turn favors the formation of precipitates.

In the replacement with supply water, the WUE-SFB of plants in treatments with nutrient solution based on $\mathrm{NaCl}$, $\mathrm{MgCl}_{2}$ and $\mathrm{KCl}$ reduced at rates of 3.74, 4.12 and $4.73 \mathrm{~g} \mathrm{~L}^{-1}$, respectively, per unit increment in $\mathrm{EC}_{\mathrm{ns}}$, whereas under $\mathrm{CaCl}_{2}$ there was a maximum efficiency $\left(56.88 \mathrm{~g} \mathrm{~L}^{-1}\right)$ at the estimated $\mathrm{EC}_{\mathrm{ns}}$ of $3.37 \mathrm{dS} \mathrm{m}^{-1}$ (Table 1 ).

The reduction of water use efficiency for fresh biomass production under salt stress conditions can be attributed to the reduction in evapotranspiration and carbon fixation by plants as the water electrical conductivity increased, consequently reducing the production per volume consumed, as observed also in other leafy vegetables such as arugula (Silva et al., 2012) and coriander (Santos Júnior et al., 2015).

Under $\mathrm{EC}_{\mathrm{ns}}$ levels of 1.7 and $6.7 \mathrm{dS} \mathrm{m}^{-1}$, there was no difference $(\mathrm{p}>0.05)$ between the cationic natures in the replacement with supply water, and for the other $\mathrm{EC}_{\mathrm{ns}}$ levels plants under predominance of $\mathrm{CaCl}_{2}$ showed greater efficiency in the replacement with supply water, whereas in the replacement with brackish water, the WUE-SFB of plants grown in the nutrient solutions based on $\mathrm{CaCl}_{2}$ and $\mathrm{MgCl}_{2}$ was higher than the others for most of the $\mathrm{EC}_{\mathrm{ns}}$ levels studied (Table 1).

This may have occurred due to reductions in the yield of plants caused by the toxic effects of excess $\mathrm{Na}^{+}$and $\mathrm{K}^{+}$, and the excess of potassium in turn can cause deficiency of magnesium and calcium, whose absorption is compromised, which leads to reduction in crop yield (Malavolta et al., 2002; Dias et al., 2016).

The WUE-SFB of plants under replacement with brackish water were maximal at the estimated $\mathrm{EC}_{\mathrm{ns}}$ levels of $4.29\left(56.55 \mathrm{~g} \mathrm{~L}^{-1}\right)$, $5.3\left(66.36 \mathrm{~g} \mathrm{~L}^{-1}\right)$ and $4.48 \mathrm{dS} \mathrm{m}^{-1}\left(66.52 \mathrm{~g} \mathrm{~L}^{-1}\right)$ for $\mathrm{NaCl}, \mathrm{CaCl}_{2}$ and $\mathrm{MgCl}_{2}$, respectively, at the same time was minimum at the estimated $\mathrm{EC}_{\mathrm{ns}}$ level of $3.69 \mathrm{dS} \mathrm{m}^{-1}\left(50.74 \mathrm{~g} \mathrm{~L}^{-1}\right)$ for $\mathrm{KCl}$ (Table 1).

In the replacement with supply water, plants exposed to nutrient solution based on $\mathrm{KCl}$ showed an average WUE-SDB of $7.67 \mathrm{~g} \mathrm{~L}^{-1}$, whereas for the other salts, maximum efficiency was estimated at 3.27, 3.66 and $3.06 \mathrm{~g} \mathrm{~L}^{-1}$ for $\mathrm{NaCl}, \mathrm{CaCl}_{2}$ and $\mathrm{MgCl}_{2}$, respectively and, except for the treatment of $1.7 \mathrm{dS} \mathrm{m}^{-1}$, plants under $\mathrm{CaCl}_{2}$ showed higher WUE-SDB (Table 1).

These results of higher WUE-SFB and WUE-SDB in the solutions with predominance of $\mathrm{CaCl}_{2}$ are consistent with those of Damato Neto et al. (2014) and this, in general, is justified, due 
Table 1. Water use efficiency in the production of shoot fresh biomass (WUE-SFB) and shoot dry biomass (WUE-SDB) of parsley plants, cv. Graúda Portuguesa, exposed to brackish nutrient solutions prepared in waters of different cationic natures $(\mathrm{CN})$, replaced with brackish water and supply water

\begin{tabular}{|c|c|c|c|c|c|c|c|c|}
\hline & \multicolumn{6}{|c|}{ EC of the nutriente solution - $\mathrm{EC}_{\mathrm{ns}}\left(\mathrm{dS} \mathrm{m}^{-1}\right.$ ) } & \multirow{2}{*}{ Regression equation } & \multirow{2}{*}{$\mathbf{R}^{2}$} \\
\hline & 1.7 & 2.7 & 3.7 & 4.7 & 5.7 & 6.7 & & \\
\hline CN & \multicolumn{8}{|c|}{$\begin{array}{c}\text { 'WUE }- \text { SFB }\left(g^{-1}\right)-\text { Supply } \\
\text { (ECns: } p \leq 0.05, C N: p \leq 0.05, \text { ECns vs CN: } p \leq 0.05, \text { CV }=7.19 \%)\end{array}$} \\
\hline $\mathrm{NaCl}$ & $50.66 \mathrm{a}$ & $53.24 \mathrm{a}$ & $45.13 \mathrm{bc}$ & $44.51 \mathrm{~b}$ & 40.02 b & $32.54 \mathrm{a}$ & $Y=-3.739^{* *} x+60.06$ & 0.88 \\
\hline $\mathrm{CaCl}_{2}$ & $51.68 \mathrm{a}$ & $55.30 \mathrm{a}$ & $51.98 \mathrm{a}$ & $55.92 \mathrm{a}$ & $46.63 \mathrm{a}$ & $28.50 \mathrm{a}$ & $Y=-2.368^{\star *} x^{2}+15.95 x+30.02$ & 0.91 \\
\hline $\mathrm{MgCl}_{2}$ & $49.49 \mathrm{a}$ & $45.44 \mathrm{~b}$ & $46.04 \mathrm{~b}$ & $43.49 \mathrm{~b}$ & $33.00 \mathrm{C}$ & $28.59 \mathrm{a}$ & $Y=-4.1249^{* \star} x+58.333$ & 0.87 \\
\hline $\mathrm{KCl}$ & $53.88 \mathrm{a}$ & $52.80 \mathrm{a}$ & $40.11 \mathrm{c}$ & $38.13 \mathrm{c}$ & $39.25 \mathrm{~b}$ & $29.29 \mathrm{a}$ & $Y=-4.731^{* *} x+62.11$ & 0.88 \\
\hline \multicolumn{9}{|c|}{$\begin{array}{c}\text { 'WUE - SFB }\left(\mathrm{g} \mathrm{L}^{-1}\right)-\text { Brackish } \\
\text { (ECns: } p \leq 0.05, \mathrm{CN}: p \leq 0.05, \text { ECns vs } \mathrm{CN}: \mathrm{p} \leq 0.05, \mathrm{CV}=5.61 \%)\end{array}$} \\
\hline $\mathrm{NaCl}$ & $54.61 \mathrm{a}$ & $56.40 \mathrm{~b}$ & $56.67 \mathrm{~b}$ & $56.09 \mathrm{~b}$ & $55.93 \mathrm{~b}$ & $55.34 \mathrm{~b}$ & $Y=-0.2432^{\star \star} x^{2}+2.0904 x+52.06$ & 0.79 \\
\hline $\mathrm{CaCl}_{2}$ & $52.56 \mathrm{a}$ & $55.13 b$ & $65.97 \mathrm{a}$ & $65.48 \mathrm{a}$ & $66.48 \mathrm{a}$ & $63.64 \mathrm{a}$ & $Y=-1.18^{* *} x^{2}+12.503^{* *} x+33.408$ & 0.89 \\
\hline $\mathrm{MgCl}_{2}$ & $55.48 \mathrm{a}$ & $62.10 \mathrm{a}$ & $64.13 \mathrm{a}$ & $66.62 \mathrm{a}$ & $65.97 \mathrm{a}$ & $58.50 \mathrm{ab}$ & $Y=-1.45^{* *} x^{2}+13.023^{* *} x+37.344$ & 0.93 \\
\hline $\mathrm{KCl}$ & $53.53 \mathrm{a}$ & $52.59 \mathrm{~b}$ & $50.30 \mathrm{C}$ & $50.45 \mathrm{c}$ & 55.22 b & $57.60 \mathrm{~b}$ & $Y=0.801^{* *} x^{2}-5.91 x+61.66$ & 0.88 \\
\hline \multicolumn{9}{|c|}{$\begin{array}{c}\text { 1WUE - SDB }\left(\mathrm{g} \mathrm{L}^{-1}\right) \text { - Supply } \\
05, \mathrm{NC}: \mathrm{p} \leq 0.05 \text {, ECns vs CN: } p \leq 0.05, \mathrm{CV}=13.30 \%)\end{array}$} \\
\hline $\mathrm{NaCl}$ & $8.14 \mathrm{a}$ & $8.38 \mathrm{ab}$ & $8.05 a b$ & $8.70 \mathrm{ab}$ & $7.26 \mathrm{~b}$ & $6.49 \mathrm{a}$ & $Y=-0.169^{\star \star} x^{2}+1.110^{\star \star} x+6.657$ & 0.83 \\
\hline $\mathrm{CaCl}_{2}$ & $9.09 \mathrm{a}$ & $9.22 \mathrm{a}$ & $9.41 \mathrm{a}$ & $9.92 \mathrm{a}$ & $8.97 \mathrm{a}$ & $7.33 \mathrm{a}$ & $Y=-0.239^{* *} x^{2}+1.753 x+6.549$ & 0.85 \\
\hline $\mathrm{MgCl}_{2}$ & $7.51 \mathrm{a}$ & $7.05 \mathrm{~b}$ & $7.60 \mathrm{~b}$ & $7.88 \mathrm{~b}$ & $5.40 \mathrm{C}$ & $4.78 \mathrm{~b}$ & $Y=-0.231^{\star \star} x^{2}+1.415^{\star \star} x+5.505$ & 0.81 \\
\hline $\mathrm{KCl}$ & $8.50 \mathrm{a}$ & $7.55 \mathrm{ab}$ & $7.22 \mathrm{~b}$ & $7.48 \mathrm{~b}$ & $8.23 a b$ & $7.05 \mathrm{a}$ & $\bar{y}=7.67 \mathrm{~g} \mathrm{~L}^{-1}$ & \\
\hline \multicolumn{9}{|c|}{$\begin{array}{c}{ }^{1} \text { WUE }- \text { SBD }\left(\mathrm{g} \mathrm{L}^{-1}\right)-\text { Brackish } \\
5, \mathrm{CN}: \mathrm{p} \leq 0.05, \text { ECns vs } \mathrm{CN}: \mathrm{p} \leq 0.05, \mathrm{CV}=8.48 \%)\end{array}$} \\
\hline $\mathrm{NaCl}$ & $10.96 \mathrm{a}$ & $10.98 \mathrm{~b}$ & $12.59 \mathrm{ab}$ & $12.68 \mathrm{ab}$ & $13.21 \mathrm{ab}$ & $13.24 a b$ & $Y=0.519^{* *} X+10.09$ & 0.86 \\
\hline $\mathrm{CaCl}_{2}$ & $10.63 \mathrm{a}$ & $11.75 \mathrm{ab}$ & $13.17 \mathrm{a}$ & $13.59 \mathrm{a}$ & $14.79 \mathrm{a}$ & $14.50 \mathrm{a}$ & $Y=0.8254^{* *} X+9.6049$ & 0.91 \\
\hline $\mathrm{MgCl}_{2}$ & $11.26 \mathrm{a}$ & $12.82 \mathrm{a}$ & $13.56 \mathrm{a}$ & $13.37 \mathrm{a}$ & $13.97 \mathrm{ab}$ & $13.76 a b$ & $Y=0.4503^{\star *} X+11.232$ & 0.71 \\
\hline $\mathrm{KCl}$ & $10.80 \mathrm{a}$ & $10.48 b$ & $11.37 b$ & $11.31 \mathrm{~b}$ & $12.69 \mathrm{~b}$ & $12.75 \mathrm{~b}$ & $Y=0.446^{\star *} X+9.61$ & 0.83 \\
\hline
\end{tabular}

${ }^{1}$ Different letters in the column indicate significant differences between cationic natures at $\mathrm{p} \leq 0.05$ by Tukey test

to the metabolic efficiencies in the use of this nutrient by these plants, with consequent increase of shoot dry weight (Table 1).

The replacement with brackish water causes linear increase in WUE-SDB, in all cationic natures studied, with an increments at rates of $0.5194,0.8254,0.4503$ and $0.446 \mathrm{~g} \mathrm{~L}^{-1}$ for $\mathrm{NaCl}, \mathrm{CaCl}_{2}, \mathrm{MgCl}_{2}$ and $\mathrm{KCl}$, respectively, per unit increase in $\mathrm{EC}_{\mathrm{ns}}$ (Table 1). Similar results were reported by FernándezGarcía et al. (2014) in henna (Lawsonia inermis L.) subjected to high salinity. These authors observed an efficient water use by plants, which allowed increases in carbon gain and carbon relocation in the roots.

For the SBPI of plants under replacement with supply water, a maximum point was observed at the estimated $\mathrm{EC}_{\mathrm{ns}}$ levels of $5.12(0.856), 4.21(0.826)$ and $4.61 \mathrm{dS} \mathrm{m}^{-1}(0.854)$ for the solutions based on $\mathrm{NaCl}, \mathrm{MgCl}_{2}$ and $\mathrm{KCl}$, respectively, whereas under $\mathrm{CaCl}_{2}$, the estimated a reduction was 0.0216 per unit increase of $\mathrm{dS} \mathrm{m}^{-1}$. When the cationic natures were compared at each $\mathrm{EC}_{\mathrm{ns}}$, there was only significant difference ( $\left.\mathrm{p} \leq 0.05\right)$ at the $\mathrm{EC}_{\mathrm{ns}}$ of $6.7 \mathrm{dS} \mathrm{m}^{-1}$ for $\mathrm{CaCl}_{2}$ (Table 2), which was higher compared to $\mathrm{KCl}$ and $\mathrm{MgCl}_{2}$ and similar to $\mathrm{NaCl}$.

In the replacement with brackish water, the SBPI decreased at rates of $0.0031,0.0053$ and 0.0051 for $\mathrm{NaCl}, \mathrm{CaCl}_{2}$ and $\mathrm{MgCl}_{2}$, respectively, whereas plants under nutrient solution based on $\mathrm{KCl}$ showed an average SBPI of 0.89 , regardless of the $\mathrm{EC}_{\mathrm{ns}}$. There was no significant difference $(\mathrm{p}>0.05)$ in this variable when the cationic natures were compared at each $\mathrm{EC}_{\mathrm{ns}}$ up to $5.7 \mathrm{dS} \mathrm{m}^{-1}$. However, at the level of $6.7 \mathrm{dS} \mathrm{m}^{-1}$, the SBPI was higher in plants grown in solutions based on $\mathrm{KCl}$ and $\mathrm{NaCl}$, which demonstrates a condition of reduced stress using these two salts (Table 2).

In a general analysis, it was observed that, in the replacement with brackish water, plants subjected to $1.7 \mathrm{dS} \mathrm{m}^{-1}$ water showed higher SBPI than those under $6.7 \mathrm{dS} \mathrm{m}^{-1}$ in all cationic natures evaluated. However, in the replacement with supply water, the opposite was observed, due to the mitigating role of the replacement with supply water in the nutrient solution, which resulted in dilution for the higher levels of salinity and, as a consequence, at these higher levels of $\mathrm{EC}_{\mathrm{ns}}$ there was a higher concentration of nutrients compared to the lower levels, leading to greater shoot development.

These results differ from those observed by Campos Júnior et al. (2018), who worked with strategies to replace the evapotranspired depth in arugula plants and found a linear decrease as the nutrient solution salinity increased, in the replacement with supply water and brackish water, with reductions of 0.0431 and 0.033 per unit increment of $\mathrm{EC}_{\mathrm{ns}}$, respectively.

In the replacement with supply water, $\mathrm{R} / \mathrm{S}$ increased linearly as a function of $\mathrm{EC}_{\mathrm{ns}}$ in all cationic natures studied, at rates of $0.0047,0.0054,0.0108$ and 0.0054 for $\mathrm{NaCl}, \mathrm{CaCl}_{2}, \mathrm{MgCl}_{2}$ and $\mathrm{KCl}$, respectively. At $\mathrm{EC}_{\mathrm{ns}}$ from 2.7 to $6.7 \mathrm{dS} \mathrm{\textrm {m } ^ { - 1 }}$, the R/S values of the plants grown in solution based on $\mathrm{NaCl}$, were more expressive than those observed in the other cationic natures (Table 2).

Probably, the increase in salinity caused toxicity through the absorption of $\mathrm{Na}^{+}$in large quantities, and such toxicity being transported to the shoots inhibited plant growth (Soares et al., 2013).

Regarding the ratio between root and shoot biomass, with replacement using brackish water, higher R/S was observed in plants grown in $\mathrm{EC}_{\mathrm{ns}} 6.7 \mathrm{dS} \mathrm{\textrm {m } ^ { - 1 }}$ water, whose values were $1.06,1.23$ and 1.14 times higher than those of the control $\left(1.7 \mathrm{dS} \mathrm{m}^{-1}\right)$ for $\mathrm{NaCl}, \mathrm{CaCl}_{2}$ and $\mathrm{MgCl}_{2}$, respectively. It should be pointed out that there was no significant variation ( $\mathrm{p}>0.05)$ with the increase of $\mathrm{EC}_{\mathrm{ns}}$ when $\mathrm{KCl}$ was used (0.1177) (Table 2). 
Table 2. Shoot biomass production index (SBPI) and root/shoot biomass ratio (R/S) of parsley plants, cv. Graúda Portuguesa, exposed to brackish nutrient solutions prepared in water with different cationic natures $(\mathrm{CN})$, and replaced with brackish water and supply water

\begin{tabular}{|c|c|c|c|c|c|c|c|c|}
\hline & \multicolumn{6}{|c|}{ EC of the nutriente solution - $\mathrm{EC}_{n \mathrm{~s}}\left(\mathrm{dS} \mathrm{m}^{-1}\right)$} & \multirow{2}{*}{ Regression equation } & \multirow[b]{2}{*}{$\mathbf{R}^{2}$} \\
\hline & 1.7 & 2.7 & 3.7 & 4.7 & 5.7 & 6.7 & & \\
\hline $\mathrm{CN}$ & \multicolumn{8}{|c|}{$\begin{array}{c}\text { 'SBPI (Supply) } \\
\text { (ECns: } p \leq 0.05, \text { CN: } p \leq 0.05, \text { ECns vs CN: } p \leq 0.05, \text { CV }=4.08 \% \text { ) }\end{array}$} \\
\hline $\mathrm{NaCl}$ & $0.753 \mathrm{a}$ & $0.825 \mathrm{a}$ & $0.838 \mathrm{a}$ & $0.848 \mathrm{a}$ & $0.843 a$ & $0.840 a b$ & $Y=-0.0108^{\star \star} x^{2}+0.1108 x+0.5721$ & 0.89 \\
\hline $\mathrm{CaCl}_{2}$ & $0.778 \mathrm{a}$ & $0.792 \mathrm{a}$ & $0.860 \mathrm{a}$ & $0.863 \mathrm{a}$ & $0.870 \mathrm{a}$ & $0.881 \mathrm{a}$ & $Y=0.0216^{* *} x+0.7506$ & 0.83 \\
\hline $\mathrm{MgCl}_{2}$ & $0.770 \mathrm{a}$ & $0.812 \mathrm{a}$ & $0.828 \mathrm{a}$ & $0.829 \mathrm{a}$ & $0.820 \mathrm{a}$ & $0.785 \mathrm{~b}$ & $Y=-0.008^{* *} x^{2}+0.0674 x+0.685$ & 0.83 \\
\hline $\mathrm{KCl}$ & $0.791 \mathrm{a}$ & $0.804 \mathrm{a}$ & $0.848 \mathrm{a}$ & $0.857 \mathrm{a}$ & $0.855 \mathrm{a}$ & $0.808 \mathrm{~b}$ & $Y=-0.0086^{* *} x^{2}+0.0793^{* *} x+0.6718$ & 0.84 \\
\hline \multicolumn{9}{|c|}{$\begin{array}{c}{ }^{1} \mathrm{SBPI} \text { (Brackish) } \\
(\mathrm{ECns}: p \leq 0.05, \mathrm{CN}: p \leq 0.05 . \mathrm{ECns} \text { vs } \mathrm{CN}: p \leq 0.05, \mathrm{CV}=1.18 \%)\end{array}$} \\
\hline $\mathrm{NaCl}$ & $0.904 \mathrm{a}$ & $0.900 \mathrm{a}$ & $0.901 \mathrm{a}$ & $0.900 \mathrm{a}$ & $0.890 \mathrm{a}$ & $0.889 a b$ & $Y=-0.0031^{*} x+0.9107$ & 0.79 \\
\hline $\mathrm{CaCl}_{2}$ & $0.899 \mathrm{a}$ & $0.897 \mathrm{a}$ & $0.894 \mathrm{a}$ & $0.893 \mathrm{a}$ & $0.880 \mathrm{a}$ & $0.873 \mathrm{c}$ & $Y=-0.0053^{* *} x+0.9119$ & 0.88 \\
\hline $\mathrm{MgCl}_{2}$ & $0.903 \mathrm{a}$ & $0.904 \mathrm{a}$ & $0.901 \mathrm{a}$ & $0.887 \mathrm{a}$ & $0.889 a$ & $0.879 \mathrm{bc}$ & $Y=-0.0051^{* *} X+0.9155$ & 0.86 \\
\hline $\mathrm{KCl}$ & $0.897 \mathrm{a}$ & $0.890 \mathrm{a}$ & $0.896 \mathrm{a}$ & $0.896 \mathrm{a}$ & $0.891 \mathrm{a}$ & $0.896 \mathrm{a}$ & $\bar{y}=0.89$ & \\
\hline \multicolumn{9}{|c|}{$\begin{array}{c}{ }^{1} \mathrm{R} / \mathrm{S} \text { (Supply) } \\
\text { (ECns: } p \leq 0.05, \mathrm{CN}: p \leq 0.05, \mathrm{ECns} \text { vs } \mathrm{CN}: \mathrm{p} \leq 0.05\end{array}$} \\
\hline $\mathrm{NaCl}$ & $0.263 \mathrm{a}$ & $0.277 \mathrm{a}$ & $0.278 \mathrm{a}$ & $0.278 a$ & $0.286 a$ & $0.291 \mathrm{a}$ & $Y=0.0047^{* *} X+0.2592$ & 0.89 \\
\hline $\mathrm{CaCl}_{2}$ & $0.196 \mathrm{a}$ & $0.199 \mathrm{~b}$ & $0.199 \mathrm{~b}$ & $0.208 a b$ & $0.209 \mathrm{~b}$ & $0.226 \mathrm{a}$ & $Y=0.0054^{* *} X+0.1839$ & 0.84 \\
\hline $\mathrm{MgCl}_{2}$ & $0.200 \mathrm{a}$ & $0.212 a b$ & $0.207 a b$ & $0.206 \mathrm{~b}$ & $0.241 \mathrm{ab}$ & $0.258 \mathrm{a}$ & $Y=0.0108^{* *} X+0.1755$ & 0.75 \\
\hline $\mathrm{KCl}$ & $0.243 \mathrm{a}$ & $0.255 a b$ & $0.260 \mathrm{ab}$ & $0.266 a b$ & $0.270 \mathrm{ab}$ & $0.270 \mathrm{a}$ & $Y=0.0054^{* *} X+0.2387$ & 0.90 \\
\hline \multicolumn{9}{|c|}{$\begin{array}{c}{ }^{1} \mathrm{R} / \mathrm{S} \text { (Brackish) } \\
\leq 0.05, \mathrm{ECns} \text { vs CN: } p \leq 0.05,\end{array}$} \\
\hline $\mathrm{NaCl}$ & $0.110 \mathrm{a}$ & $0.113 \mathrm{a}$ & $0.113 \mathrm{a}$ & $0.113 \mathrm{a}$ & $0.114 \mathrm{~b}$ & $0.118 b$ & $Y=0.0013^{*} x+0.1086$ & 0.78 \\
\hline $\mathrm{CaCl}_{2}$ & $0.112 \mathrm{a}$ & $0.114 \mathrm{a}$ & $0.118 \mathrm{a}$ & $0.126 a$ & $0.131 \mathrm{a}$ & $0.135 \mathrm{a}$ & $Y=0.005^{\star \star} X+0.1019$ & 0.97 \\
\hline $\mathrm{MgCl}_{2}$ & $0.113 \mathrm{a}$ & $0.115 \mathrm{a}$ & $0.119 \mathrm{a}$ & $0.120 \mathrm{a}$ & $0.126 a b$ & $0.130 a b$ & $Y=0.0032^{* *} X+0.1072$ & 0.95 \\
\hline $\mathrm{KCl}$ & $0.115 a$ & $0.120 \mathrm{a}$ & $0.116 a$ & $0.115 a$ & $0.121 a b$ & $0.116 \mathrm{~b}$ & $\bar{y}=0.1177$ & \\
\hline
\end{tabular}

${ }^{1}$ Different letters in the column indicate significant differences between cationic natures at $\mathrm{p} \leq 0.05$ by Tukey test

For this same variable, the analysis of cationic natures at each $\mathrm{EC}_{\mathrm{ns}}$ tested showed a difference $(\mathrm{p} \leq 0.05)$ between the $\mathrm{R} / \mathrm{S}$ of plants grown in a solution based on $\mathrm{NaCl}$ and $\mathrm{CaCl}_{2}$ under 5.7 and $6.7 \mathrm{dS} \mathrm{m}^{-1}$. More expressive means were observed for the solutions based on $\mathrm{CaCl}_{2}$, which, despite an excess of calcium in the nutrient solution due to the precipitation of calcium phosphate in the reservoir, did not promote adequate absorption of water and nutrients by the roots, for a good development of the shoots (Table 2).

Likewise, Silva et al. (2013b) analyzing arugula plants and Bione et al. (2014) in the cultivation of basil, both using NFT hydroponics, and Sá et al. (2013), using hydroponics, observed

Table 3. Water contents in the plant (WCP), shoots (WCS) and roots (WCR) of parsley plants, cv. Graúda Portuguesa, exposed to brackish nutrient solutions prepared in water with different cationic natures $(\mathrm{CN})$, replaced with brackish water and supply water

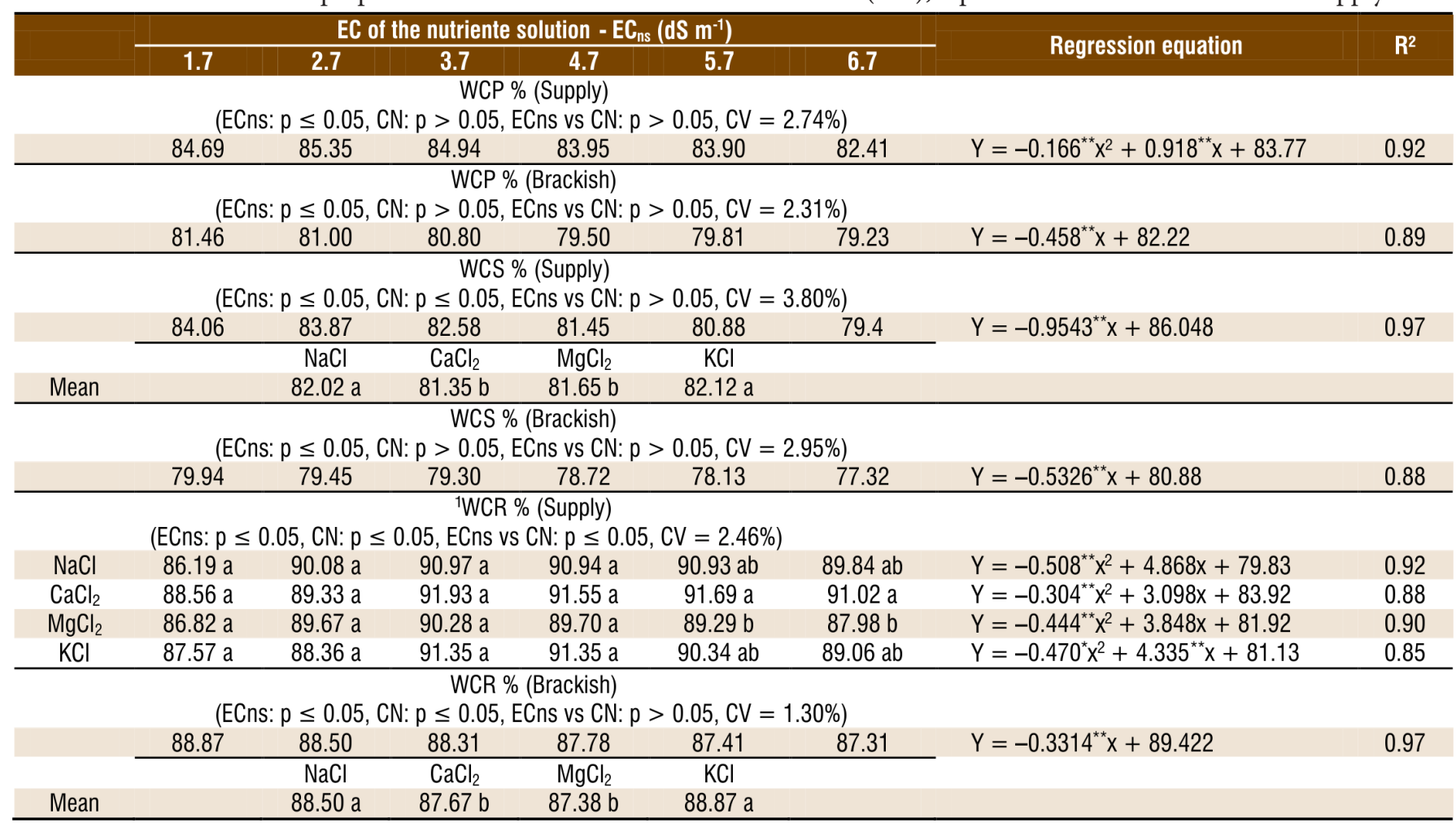

${ }^{1}$ Different letters in the column indicate significant differences between cationic natures at $\mathrm{p} \leq 0.05$ by Tukey test 
that the increase in root/shoot ratio is understood as a reaction of the plant to the stress, which promotes increased formation of root mass to improve the absorption of water and nutrients or reduced accumulation of dry matter in the shoots, leading to reduction in the area of transpiration.

In relation to the water content in the plants (WCP), under replacement with supply water, maximum moisture (85.04\%) was obtained in plants treated with all cationic natures tested at the estimated $\mathrm{EC}_{\mathrm{ns}}$ of $2.76 \mathrm{dS} \mathrm{m}^{-1}$. In the replacement with brackish water, WCP decreased linearly by $0.458 \%$ for every increment of $\mathrm{dS} \mathrm{m} \mathrm{m}^{-1}$ in the solution (Table 3 ). In both replacements, the water content in the plant was below the average value of $88.7 \%$ observed for parsley (TACO, 2011).

Under replacement with supply water, WCS decreased by $0.954 \%$ per unit increment of $\mathrm{EC}_{\mathrm{ns}}$, causing a loss of $5.86 \%$ within the proposed range of salinity ( 1.7 to $\left.6.7 \mathrm{dS} \mathrm{m}^{-1}\right)$. A similar situation, but with smaller loss, occurred when the replacement was made with brackish water, which led to a linear reduction of $0.53 \%$ per unit increase of $\mathrm{dS}^{-1}$. In a comparison of the effects of the cationic nature, under replacement with supply water, there was no difference $(\mathrm{p}>0.05)$ between the values of WCS in plants under solutions based on $\mathrm{CaCl}_{2}$ and $\mathrm{MgCl}_{2}$, and their results differed $(\mathrm{p}<0.05)$ and were lower than those obtained with $\mathrm{NaCl}$ and $\mathrm{KCl}$ (Table 3 ).

In the replacement with supply water, WCR was maximum $\left(91.48,91.81,90.25\right.$ and 91.11) at the estimated $\mathrm{EC}_{\mathrm{ns}}$ levels of $4.79,5.09,4.33$ and $4.61 \mathrm{dS} \mathrm{m}^{-1}$ for $\mathrm{NaCl}, \mathrm{CaCl}_{2}, \mathrm{MgCl}_{2}$ and $\mathrm{KCl}$, respectively. The analysis of the cationic nature at each $\mathrm{EC}_{\mathrm{ns}}$ studied showed that, at the levels of 5.7 and $6.7 \mathrm{dS} \mathrm{m}^{-1}$, the WCR of plants in the solution based on $\mathrm{CaCl}_{2}$ stood out $(\mathrm{p}<0.05)$, with less expressive results observed under $\mathrm{MgCl}_{2}$ (Table 3).

In the case of replacement with brackish water, WCR decreased by $0.331 \%$ per unit increment of salinity, a decrease that was also observed by Campos Júnior et al. (2018) with a unit reduction of $0.8587 \%$ and a variation of $7.72 \%$ within the salinity range studied ( 1.5 to $\left.9.0 \mathrm{dS} \mathrm{m}^{-1}\right)$. In relation to the cationic nature, the highest means for WCR were found under circulation with solution based on $\mathrm{KCl}(88.87 \%)$ and $\mathrm{NaCl}(88.5 \%)$ on average, higher than the means obtained with $\mathrm{CaCl}_{2}(87.67 \%)$ and $\mathrm{MgCl}_{2}(87.38 \%)$ (Table 3).

\section{Conclusions}

1. Increase of electrical conductivity of water in nutrient solution decreases the water contents in the shoots and roots, shoot biomass production index and water use efficiency; however, when the evapotranspired depth was replaced with supply water, these effects were reduced.

2. In the replacement with brackish water, the water use efficiency, water content, root/shoot ratio and shoot biomass production index of the plants under electrical conductivity higher than $5.7 \mathrm{dS} \mathrm{m}^{-1}$ in nutrient solution based on $\mathrm{CaCl}_{2}$ were not hampered, due to the precipitation observed in the reservoirs.

3. The increase in the electrical conductivity of the nutrient solution under replacement with supply water and each type of brackish water inhibited the water use efficiency, shoot biomass production index and water content of the plants.
4. In general, the order of the effects by the cationic natures as a function of the replacement of the evapotranspired water was: a) replacement with supply water: $\mathrm{CaCl}_{2}$ and $\mathrm{NaCl}>\mathrm{KCl}$ $>\mathrm{MgCl}_{2}$; b) replacement with brackish water: $\mathrm{CaCl}_{2}$ and $\mathrm{NaCl}$ $>\mathrm{MgCl}_{2}>\mathrm{KCl}$.

\section{Literature Cited}

Abrahão, C.; Bôas, R. L. V.; Bull, L. T. Relação K:Ca:Mg na solução nutritiva para a produção de minitomate cultivado em substrato. Irriga, v.19, p.214-224, 2014. https://doi.org/10.15809/ irriga.2014v19n2p214

Alvares, C. A.; Stape, J. L.; Centelhas, P. C.; Gonçalves, J. L. de M.; Sparovek, G. Köppen's climate classification map for Brazil. Meteorologische Zeitschrift, v.22, p.711-728, 2013. https://doi. org/10.1127/0941-2948/2013/0507

Benincasa, M. M. P. Análise de crescimento de plantas: Noções básicas. 2.ed. Jaboticabal: FUNEP, 2003. 42p.

Bernardes, P. M.; Mengarda, L. H. G.; Lopes, J. C.; Nogueira, M. U.; Rodrigues, L. L. Qualidade fisiológica de sementes de repolho de alta e baixa viabilidade sob estresse salino. Nucleus, v.12, p.77-86, 2015. https://doi.org/10.3738/1982.2278.1105

Bione, M. A. A.; Paz, V. P. da S.; Silva, F. da; Ribas, R. F.; Soares, T. M. Crescimento e produção de manjericão em sistema hidropônico NFT sob salinidade. Revista Brasileira de Engenharia Agrícola e Ambiental, v.18, p.1228-1234, 2014. https://doi.org/10.1590/18071929/agriambi.v18n12p1228-1234

Borges, C. T.; Deuner, C.; Rigo, G. A.; Oliveira, S. de; Moraes, D. M. de. O estresse salino afeta a qualidade fisiológica de sementes de rúcula? Enciclopédia Biosfera, v.10, p.1049-1057, 2014.

Campos Júnior, J. E.; Santos Júnior, J. A.; Silva, Ê. F. de F. e; Martins, J. B.; Rolim, M. M. Consumption, efficiency and water content of arugula under different management of brackish nutritional solutions. Engenharia Agrícola, v.38, p.885-892, 2018. https://doi. org/10.1590/1809-4430-eng.agric.v38n6p885-892/2018

Damato Neto, J.; Santos, M. A. dos; Soares, A. C.; Matos Neto, F. da C.; Souza, C. M. de. Avaliação do sistema radicular e eficiência nutricional de cálcio e magnésio em mudas de Coffea arabica e Coffea canephora. Revista Verde de Agroecologia e Desenvolvimento Sustentável, v.9, p.307-312, 2014.

Dias, N. da S.; Blanco, F. F.; Souza, E. S.; Ferreira, J. F. S.; Souza Neto, O. N. de; Queiroz, I. S. R. Efeitos dos sais na planta e tolerância das culturas à salinidade. In: Gheyi, H. R.; Dias, N. da S.; Lacerda, C. F. de; Gomes Filho, E. (eds.). Manejo da salinidade na agricultura: Estudo básico e aplicados. 2.ed. Fortaleza: INCTSal, 2016. Cap.11, p.151-162.

Fernández-García, N.; Olmos, E.; Bardisi, E.; Garma, J. G. de la; LópezBerenguer, C.; Rubio-Asensio, J. S. Intrinsic water use efficiency controls the adaptation to high salinity in a semi-arid adapted plant, henna (Lawsonia inermis L.). Journal of Plant Physiology, v.171, p.64-75, 2014. https://doi.org/10.1016/j.jplph.2013.11.004

Ferreira, D. F. Sisvar: A computer statistical analysis system. Ciência e Agrotecnologia, v.35, p.1039-1042, 2011. https://doi.org/10.1590/ S1413-70542011000600001

Furlani, P. R.; Silveira, L. C. P.; Bolonhezi, D.; Faquin, V. Cultivo hidropônico de plantas. Campinas: Instituto Agronômico de Campinas, 1999. 52p. Boletim Técnico, 180 
Holanda, J. S.; Amorim, J. R. A.; Ferreira Neto, M.; Holanda, A. C.; Sá, F. V. da S. Qualidade da água para irrigação. In: Gheyi, H. R.; Dias, N. da S.; Lacerda, C. F. de; Gomes Filho, E. (eds.). Manejo da salinidade na agricultura: Estudos básicos e aplicados. 2.ed. Fortaleza: INCTSal, 2016. Cap.4, p.35-47.

Lima, G. S. de; Nobre, R. G.; Gheyi, H. R.; Soares, L. A. dos A.; Azevedo, C. A. V. de; Lima, V. L. A. de. Salinity and cationic nature of irrigation water on castor bean cultivation. Revista Brasileira de Engenharia Agrícola e Ambiental, v.22, p.267-272, 2018. https:// doi.org/10.1590/1807-1929/agriambi.v22n4p267-272

Malavolta, E.; Gomes, F. P.; Alcarde, J. C. Adubos e adubações. São Paulo: Nobel, 2002. 199p.

Melo, A. M. T.; Betti, J. A.; Pizzinatto, M. A.; Dechen, S. C. F.; Freitas, S. S. Soluções nutritivas. Campinas: Instituto Agronômico de Campinas, 1999. Boletim Técnico, 1

Nobre, R. G.; Lima, G. S. de; Gheyi, H. R.; Soares, L. A. dos A.; Silva, A. O. da. Crescimento, consumo e eficiência do uso da água pela mamoneira sob estresse salino e nitrogênio. Revista Caatinga, v.27, p.148-158, 2014.

Paulus, D.; Paulus, E.; Nava, G. A.; Moura, C. A. Crescimento, consumo hídrico e composição mineral de alface cultivada em hidroponia com águas salinas. Revista Ceres, v.59, p.110-117, 2012. https://doi.org/10.1590/S0034-737X2012000100016

Sá, F. V. da S.; Brito, M. E. B.; Melo, A. S. de; Antônio Neto, P.; Fernandes, P. D.; Ferreira, I. B. Produção de mudas de mamoeiro irrigadas com água salina. Revista Brasileira de Engenharia Agrícola e Ambiental, v.17, p.1047-1054, 2013. https://doi. org/10.1590/S1415-43662013001000004

Santos Júnior, J. A.; Gheyi, H. R.; Cavalcante, A. R.; Dias, N. da S.; Medeiros, S. S. de. Produção e pós-colheita de flores de girassóis sob estresse salino em hidroponia de baixo custo. Engenharia Agrícola, v.36, p.420-432, 2016. https://doi.org/10.1590/18094430-Eng.Agric.v36n3p420-432/2016

Santos Júnior, J. A.; Gheyi, H. R.; Cavalcante, A. R.; Medeiros, S. S. de; Dias, N. da S.; Santos, D. N. dos. Water use efficiency of coriander produced in a low-cost hydroponic system. Revista Brasileira de Engenharia Agrícola e Ambiental, v.19, p.1152-1158, 2015. https://doi.org/10.1590/1807-1929/agriambi.v19n12p1152-1158
Silva, A. O. da; Klar, A. E.; Silva, Ê. F. de F. e; Tanaka, A. A.; Silva Júnior, J. F. Relações hídricas em cultivares de beterraba em diferentes níveis de salinidade do solo. Revista Brasileira de Engenharia Agrícola e Ambiental, v.17, p.1143-1151, 2013a. https://doi. org/10.1590/S1415-43662013001100003

Silva, A. O. da; Soares, T. M.; Silva, Ê. F. de F. e; Santos, A. N. dos; Klar, A. E. Consumo hídrico da rúcula em cultivo hidropônico NFT utilizando rejeitos de dessalinizador em Ibimirim-PE. Irriga, v.17, p.114-125, 2012. https://doi.org/10.15809/irriga.2012v17n1p114

Silva, F. V. da; Duarte, S. N.; Lima, C. J. G. de S.; Dias, N. da S.; Santos, R. S. da S.; Medeiros, P. R. F. de. Cultivo hidropônico de rúcula utilizando solução nutritiva salina. Revista Brasileira de Ciências Agrárias, v.8, p.476-482, 2013b. https://doi.org/10.5039/agraria.v8i3a1689

Silva, J. S. da; Paz, V. P. da S.; Soares, T. M.; Almeida, W. F. de; Fernandes, J. P. Production of lettuce with brackish water in NFT hydroponic system. Semina: Ciências Agrárias, v.39, p.947-962, 2018. https://doi.org/10.5433/1679-0359.2018v39n3p947

Silva, M. G. da; Soares, T. M.; Oliveira, I. de S.; Santos, J. C. da S.; Pinho, J. S.; Freitas, F. T. O. de. Produção de coentro em hidroponia NFT com o uso de águas salobras para reposição do consumo evapotranspirado. Revista Brasileira de Agricultura Irrigada, v.9, p.246-258, 2015. https://doi.org/10.7127/rbai.v9n400319

Soares, L. A. dos A.; Lima, G. S. de; Nobre, R. G.; Gheyi, H. R.; Pereira, F. H. F. Fisiologia e acúmulo de fitomassa pela mamoneira submetida a estresse salino e adubação nitrogenada. Revista Verde de Agroecologia e Desenvolvimento Sustentável, v.8, p.247-256, 2013.

Soares, T. M.; Duarte, S. N.; Silva, Ê. F. de F. e; Paz, V. P. da S.; Oliveira, J. L. B. Uso de águas salobras em sistemas hidropônicos de cultivo. In: Gheyi, H. R.; Dias, N. da S.; Lacerda, C. F. de; Gomes Filho, E. (eds.). Manejo da salinidade na agricultura: Estudo básico e aplicados. 2.ed. Fortaleza: INCTSal, 2016. Cap.23, p.373-390.

TACO - Tabela Brasileira de Composição de Alimentos. 4.ed. rev. ampl. Campinas: Núcleo de Estudos e Pesquisas em Alimentação da UNICAMP, 2011. 161p.

Terraza, S. P.; Terán, G. E. G.; Carrasco, W. R.; Verdugo, S. H. Relación $\mathrm{NO}_{3}^{-} / \mathrm{K}^{+}$en la solución nutritiva en el crecimiento y rendimiento de pepino hidropônico. Revista Mexicana de Ciencias Agrícolas, v.7, p.1389-1400, 2016. https://doi.org/10.29312/remexca.v7i6.201 